\title{
Using Tickets in Employment Standards Inspections: Deterrence as Effective Enforcement in Ontario, Canada?
}

\author{
Rebecca Casey \\ York University \\ Eric Tucker \\ Osgoode Hall Law School of York University, etucker@osgoode.yorku.ca \\ Leah F. Vosko \\ York University \\ Andrea M. Noack \\ Ryerson University
}

Source Publication:

29 Economic and Labour Relations Review 228-249 DOI: 10.1177/1035304618769772

Follow this and additional works at: https://digitalcommons.osgoode.yorku.ca/scholarly_works

Part of the Labor and Employment Law Commons

\section{Repository Citation}

Casey, Rebecca; Tucker, Eric; Vosko, Leah F.; and Noack, Andrea M., "Using Tickets in Employment Standards Inspections: Deterrence as Effective Enforcement in Ontario, Canada?" (2018). Articles \& Book Chapters. 2736.

https://digitalcommons.osgoode.yorku.ca/scholarly_works/2736

This Article is brought to you for free and open access by the Faculty Scholarship at Osgoode Digital Commons. It has been accepted for inclusion in Articles \& Book Chapters by an authorized administrator of Osgoode Digital Commons. 


\title{
Using tickets in employment standards inspections: Deterrence as effective enforcement in Ontario, Canada?
}

\author{
Rebecca Casey \\ York University, Canada \\ Eric Tucker \\ Osgoode Hall Law School, Canada \\ Leah F. Vosko \\ York University, Canada \\ Andrea M. Noack \\ Ryerson University, Canada
}

\section{Corresponding Author:}

Leah F. Vosko, Professor and Canada Research Chair in the Political Economy of Gender \& Work, 6 I 8 Kaneff Tower, York University, 4700 Keele Street, Toronto, Ontario, Canada, M3J IP3. Email: Ivosko@yorku.ca

\begin{abstract}
It is widely agreed that there is a crisis in labour/employment standards enforcement. A key issue is the role of deterrence measures that penalise violations. Employment standards enforcement in Ontario, like in most jurisdictions, is based mainly on a compliance framework promoting voluntary resolution of complaints and, if that fails, ordering restitution. Deterrence measures that penalise violations are rarely invoked. However, the Ontario government has recently increased the role of proactive inspections and tickets, a low-level deterrence measure which imposes fines of \$295 plus victim surcharges. In examining the effectiveness of the use of tickets in inspections, we begin by looking at this development in the broader context of employment standards enforcement and its historical trajectory. Then, using administrative data from the Ministry of Labour, we examine when and why tickets are issued in the course of workplace inspections. After demonstrating that even when ticketable violations are detected, tickets are issued only rarely, we explore factors associated with an increased likelihood of an inspector issuing a ticket. Finally, we
\end{abstract}


consider how the overall deterrent effect of workplace inspections is influenced by the use or nonuse of deterrence tools.

\section{JEL codes: J88}

\section{Keywords}

Canada, compliance, deterrence, employment standards, labour standards, Ontario, tickets, violations

\section{Introduction}

While we often hear about struggles to raise the minimum wage and other labour standards, the issue of their enforcement receives far less attention. Yet without effective enforcement, improved labour standards will fail to achieve their objective. While this observation is not novel (eg, Burns 1926: 146-47), researchers repeatedly find that labour standards enforcement fails to make workers' rights real. A recent United States investigation concluded that '[w]age laws are poorly enforced, with workers often unable to recover back pay even after government rules in their favor' (Levine, 2018). Dickens (2012: 206-07) found that 'enforcement in Britain is flawed in that too much reliance is placed on individuals having to assert and pursue their statutory employment rights, which generally require only passive compliance from employers ...'. In Australia, Hardy (2016: 107) concludes that ' $[\mathrm{t}]$ he compliance and enforcement problems which have been brought to light in the past year are complex, challenging and profound'.

While there is no simple answer to the question of how to strengthen labour standards enforcement, deterrence is generally agreed to play an important role. Yet many studies find that employers are rarely penalised for violating their workers' rights. In the province of Ontario, Canada, employment standards (ES) enforcement has focused principally on encouraging voluntary compliance and, if that fails, ordering restitution. Deterrence measures that penalise violations are rarely invoked. This approach to the enforcement of protective employment laws has a long history (Tucker, 1990) and many worker advocates and academic researchers have argued that it results in regulatory failure (Bernstein et al., 2003).

The limited role of deterrence measures in Canada is not unique to Ontario. For example, Gesualdi-Fecteau and Vallée (2016) have found little use of penal provisions in Quebec, while 
researchers in British Columbia (BC) report that proactive enforcement has been abandoned and that enforcement staff has been reduced by half since 2000/2001 despite a $25 \%$ increase in establishments with employees (BC Employment Standards Coalition, 2017).

In this article, we scrutinise the use of tickets in ES enforcement in Ontario. Tickets are a lowlevel deterrence measure made available to Employment Standards Officers (ESOs) in 2004 when the government amended regulations under the Provincial Offences Act (POA) to make 58 violations of the Employment Standards Act (ESA) ticketable and subject to fines of \$295 plus victim surcharges. In particular, we focus on the use of tickets in the context of workplace inspections, which is one of two ways in which ESA violations may come to the attention of ESOs, the other way being via individual complaints.

Most enforcement resources in Ontario are dedicated to addressing individual workers' complaints that their employers have violated their rights. Indeed, this is the principal way in which violations are detected and resolved. Nevertheless, in response to widespread criticism of the limitations of a complaints-based enforcement model, in recent years the Ontario government increased the role of proactive workplace inspections and introduced a program of targeted inspections, known as blitzes. This initiative represents a limited but potentially meaningful change in the government's overall approach to ES enforcement and, therefore, merits scrutiny in order to assess how deterrence measures are used in this particular context.

The analysis begins with a brief discussion of the role of deterrence in ES enforcement and the deterrence measures available under the ESA. It then turns to a detailed empirical examination of the use of tickets in workplace inspections, including the prevalence of tickets, the types of violations that result in tickets, and when and why tickets are used, with a focus on workplaces that have been inspected more than once. We conclude with a discussion of the overall use of tickets in ES enforcement, looking at both the pattern of practice in Ontario and broader questions about the use of low-level deterrence measures in regulatory enforcement systems.

\section{Deterrence in ES enforcement}

Approaches to regulatory enforcement are either compliance-focused or deterrence-focused. Compliance-focused approaches prioritise the role of the state in assisting duty holders to meet their legal obligations through education about what those obligations are and how best to meet them. The assumption is that most employers want to comply with the law and that violations are 
largely the result of ignorance or incompetence. Therefore, the most productive approach to securing compliance is for ESOs to win the trust of employers by demonstrating a non-punitive approach, gently guiding employers onto the right path while ensuring that employees who have been deprived of their statutory entitlements get restitution. In contrast, deterrence-focused approaches, assume that much, if not most, wrongdoing is based on a calculation of the costs of compliance relative to the risks of non-compliance. If duty holders believe that there is little risk of violations being detected or that if they are detected the severity of punishment is low, then they will more likely to violate the law. Therefore, effective enforcement requires the state to change that calculation by increasing the risk of detection and/or the severity of punishment. Such an approach will specifically deter individuals and will also produce general deterrence as knowledge of the government's approach to enforcement becomes widespread.

Recently, regulators and researchers have recognised that effective enforcement requires a combination of compliance and deterrence. One such model is responsive regulation (Ayres and Braithewaite, 1992) which posits that regulators should initially approach duty holders as wellintentioned and provide compliance assistance, resorting to deterrence measures of increasing severity only if compliance or low-level deterrence measures fail. This set of assumptions yields the well-known enforcement pyramid. Although it is expected that deterrence measures will not be needed in most cases, it is vital that they are available and used when necessary. A second, more recent approach is the strategic enforcement model developed by Weil $(2008,2010,2014)$. Weil looks at the contextual factors that increase the likelihood of employer ES violations, including the fissuring of employer responsibility that results in shifting work out of large firms and into environments subject to intense competitive pressures. Strategic enforcement aims to respond to this environment by building on four principles: prioritisation, deterrence, sustainability, and systemic effects. Clearly, deterrence plays a larger role in strategic enforcement than in responsive regulation, but in both scenarios, it remains only one element of a broader regulatory approach in which compliance strategies play a role, including working with lead firms to secure their cooperation in achieving compliance by their franchisees, contractors, or suppliers.

Despite the differences between these models, they both situate deterrence as an essential element of an effective regulatory enforcement strategy. Yet in Ontario relatively few ES violations result in the use of a low-level deterrence measure by an ESO, and higher-level 
deterrence measures appear to be used only when employers defy the authority of the state by refusing to comply with an order to pay or interfere with an ESO.

Notwithstanding this general finding, it is important to consider how deterrence operates in particular components of the enforcement process. As noted, ES enforcement in Ontario is largely complaint-based. Three-quarters of all violations are detected through complaints and much of the Ministry of Labour's (MOL's) Employment Standards Program staff and resources are devoted to complaint resolution. Nevertheless, the role of proactive inspections grew steadily after the province's Auditor General drew attention to the virtual disappearance of workplace inspections in 2004. In more recent years, the MOL has adopted a targeted inspection strategy that seeks to prioritise sectors of the economy or the workforce where it believes that ES violations are more frequent. In light of this shift, a study of the use of deterrence measures and tickets in particular during inspections is warranted.

Before turning to the empirical dimension of the investigation, it is helpful to examine the deterrence tools available in ES enforcement in Ontario. Rather than begin with low-level deterrence tools, for historical reasons we start by describing the most severe deterrence tool, the criminal law. The architecture of the Canadian constitution draws a very sharp distinction between criminal and regulatory law. This distinction flows from the fact that criminal law is a matter of exclusive federal jurisdiction and so provinces cannot create criminal penalties for the violation of provincial statutes. Employment regulation is considered a matter of property and civil rights and therefore is principally a provincial responsibility; as a result, violations of the ESA cannot be made crimes by the province. However, the federal government may choose to treat some employer misconduct that also involves breaches of provincial statutes as crimes, especially where there is an element of intentional behaviour. Thus, in 1935, the federal government criminalised the intentional violation of minimum wage laws, a provision that remained on the books until 1954, although for a variety of reasons it was unenforceable (Tucker, 2017).

Provincial laws normally make their violation a regulatory offence. For example, the ESA makes it an offence to contravene the Act or its regulations, or to fail to comply with an order or direction issued by an ESO (s. 132). Regulatory offences are strict liability offences in that there is no need to prove intent, only that the law was violated. Individuals are liable to be fined up to $\$ 50,000$ or imprisoned for up to 12 months. Corporations are liable to be fined up to $\$ 100,000$ for a first offence, $\$ 250,000$ for a second offence, and $\$ 500,000$ for a third or subsequent offence. 
There are also provisions allowing directors and officers of corporations to be prosecuted and punished under certain circumstances (ss.136, 137). Prosecutions of this kind are initiated by a formal charge known as an 'information' and the procedures to be followed are governed by Part III of the POA.

For many years, Part III prosecutions were the only deterrence tool available to enforce the ESA, yet they were rarely initiated. In addition to the general aversion of enforcement officials to act like police (Hawkins, 1984; Kagan, 1984), Part III prosecutions are time-consuming. ESOs can only recommend prosecutions; the ultimate decision is made by the Legal Services Branch (LSB) of the MOL, acting as Crown. This cumbersome process led regulators to develop lower-level deterrence tools that could be applied with greater ease. In 2000, the government amended the ESA to give ESOs the power to issue a Notice of Compliance (NOC). Section 113 of the ESA provides: "If an employment standards officer believes that a person has contravened a provision of this Act, the officer may issue a notice to the person setting out the officer's belief and the prescribed penalty for that contravention." Crucially, NOCs may be issued for any contravention of the Act and so are widely available. Ontario Regulation 289/01 sets out the prescribed penalties: at the time of writing, $\$ 250$ for a first contravention, $\$ 500$ for a second contravention, and \$1,000 for a third or subsequent contravention. NOCs can be served in a variety of ways, including mail, fax, and email (s. 95). An entity served with a NOC is deemed to be guilty and liable to pay the penalty unless they apply to the Ontario Labour Relations Board for a review within 30 days. NOCs are best conceptualised as an administrative penalty, rather than a regulatory offence, since they are not governed by the POA and the judiciary is not involved at any stage.

The second low-level compliance tool, tickets, was created in 2004 by an amendment to Regulation 950 (O.Reg. 162/04) of the POA, and aimed ostensibly to protect vulnerable employees in instances of relatively minor offences (Ontario Ministry of Labour, 2004). Violations of specific statutes can be prosecuted by a 'certificate of offence' or ticket, under Part I of the POA, a simpler procedure than a Part III prosecution. Importantly, tickets can be issued by ESOs - who are provincial offence officers - but, unlike NOCs, they must be served personally on the accused. ESOs do not need to involve the ESB in the decision to issue a ticket, although the LSB may become involved if the accused contests a ticket. There are currently a total of 58 ticketable ESA violations that can be categorised into three main groupings: administrative violations (such as record keeping), monetary violations (failure to pay wages or failure to pay vacation pay), and 
non-monetary substantive violations (hours of work exceeds limit). The amount of the fine is set by the Chief Justice of the Ontario Court of Justice and currently is \$295. As well, a victim fine surcharge and an administrative fee are added to each fine (O.Reg. 161/00) so that the total payable for each ticket is $\$ 360$.

Theoretically, a NOC could be issued for each ticketable violation. However, the MOL Administrative Manual for Employment Standards (AMES) (2017, S. 7.5.7) stipulates that ESOs should issue tickets rather than NOCs, and this is the practice of ESOs (Vosko, Noack and Tucker, 2016). In fact, NOCs are used quite infrequently in the context of workplace inspections (Table 1 ), and for that reason we focus on the use of tickets.

The AMES (S. 7A.2) also states that the objective of prosecution policy for both Part I tickets and Part III prosecutions is to ensure compliance with minimum standards set out in the ESA. It further states that the purpose of prosecution is both specific and general deterrence and that the decision to prosecute should be based on a number of considerations once it has been determined there is sufficient evidence to establish the offence. These considerations include: the seriousness or gravity of the offence, the history of compliance, mitigating or aggravating circumstances, the availability of effective alternatives to prosecution, program identification of targeted contraventions, and the necessity of maintaining public confidence in the legislation. The manual elaborates on these considerations (S. 7A.3) and then advises ESOs generally to use tickets for first offenders of less serious offences (S. 7A.4.1).

\section{The use of tickets in workplace inspections}

\section{A. Methods}

In examining the use of tickets in workplace inspections, we draw on the Ontario MOL's Employment Standards Information System (ESIS), a repository of data on Ontario's ES enforcement that is not otherwise publically available. ${ }^{1}$ As ESIS was designed for administrative purposes, such as tracking and record-keeping, rather than for research purposes, it has not undergone the same quality control and data verification process as survey data from large statistical agencies. However, as a complete record of workplace inspections conducted under the ESA, ESIS data provide key insights into ESA enforcement unavailable from any other source. Our focus is on workplace inspections completed from 2012/13 to 2015/16, the most recent fiscal ${ }^{2}$ years for which near-complete data are available. Since we rely on the fiscal year in which an 
inspection was conducted, these findings may differ from reports issued by the MOL, which typically report tickets using their conviction date.

\section{B. The scope and types of inspections}

Workplace inspections in Ontario focus primarily on 11 standards, which are stipulated in the AMES (Ch. 4, 3):

- Poster requirements

- Wage statements

- Unauthorized deductions

- Record keeping

- Hours of work

- Eating periods

- Overtime pay

- Minimum wage

- Public holidays

- Vacation with pay

- Temporary help agencies charging employees fees and providing information.

A full inspection will cover all 11 standards, but sometimes inspections will be limited to a subset of them. Other times, albeit rarely, standards outside this list, such as unpaid wages, will also be assessed.

Inspections can be divided conceptually into three main types. The first type are expanded investigations launched when an ESO detects a violation from an individual complaint that is included in the 11 standards that are investigated during an inspection and has reason to believe other employees are affected similarly. Expanded investigations bridge the reactive/proactive divide insofar as they are initiated by a complaint, but become proactive by seeking to discover whether non-complaining employees suffered the same violation. The other two types of inspections, blitz and regular inspections, are purely proactive insofar as they are undertaken as part of a planned program of inspections. Targeted or blitz inspections are initiated by the MOL to investigate a particular sector in which it suspects a high incidence of ES violations. For example, the MOL conducted blitz inspections of Temporary Help Agencies in 2012 and 2015 and of nail 
salons and fast-food restaurants in the context of the vulnerable workers blitz in 2013. Regular inspections are more random. ESOs select employers for inspection based on regional priorities or individual discretion. ${ }^{3}$

\section{The prevalence of tickets in inspections}

Two different measures are useful when examining the prevalence of tickets in workplace inspections. The first considers the number of tickets in relation to the total number of ticketable violations detected and recorded in an inspection. The second considers the number of tickets in relation to the number of inspections that detected and recorded a ticketable violation. ${ }^{4}$ Both measures are important to consider because, as we note below, researchers have investigated the impact of an inspection with a single deterrent measure that is independent of the total number of violations detected.

Table 1 provides data on the use of tickets and NOCs both in workplace inspections and for individual complaints, relative to the number of violations that could be ticketed or subject to a NOC. Foremost, the table shows that ESOs adhere to the MOL's policy of favouring tickets over NOCs, regardless of whether a violation is detected in an inspection or in a complaint. NOCs and tickets are both used far less frequently in complaints; however, for both complaints and inspections, NOCs are used typically for less than $1 \%$ of all violations. Whereas tickets are used slightly more often, they are issued far more frequently for ticketable violations detected in workplace inspections than for those detected in complaints. Reasons for this difference include the possibility that in the context of complaints ESOs are more focused on dispute resolution than on deterrence. However, the fact that tickets are used much more frequently in the context of inspections than in the context of complaints supports our decision to investigate deterrence practices in workplace inspections separate from complaints.

\section{TABLE 1 HERE}

In 2012/13, 6\% of ticketable violations detected in workplace inspections resulted in tickets, whereas in the three subsequent years for which data are available, this percentage rose to roughly 9\%. Table 2 presents data on the prevalence of tickets using the number of inspections as the

denominator. It thereby considers the practice of ticketing in relation to the number of inspections with ticketable violations and presents a very different picture; by this measure, the prevalence of 
ticketing more than doubles, ranging between $16 \%$ and $22 \%$, although the prevalence of ticketing in 2012/13 is anomalously low compared to subsequent years. The percentage of inspections with tickets is greater than the percentage of ticketed violations because an ESO may find multiple ticketable violations on an inspection but can choose to only issue tickets for a select number, a practice discussed below.

\section{TABLE 2 HERE}

\section{Types of violations resulting in tickets}

Although tickets are more commonly issued in the context of workplace inspections than individual complaints, little is known about which types of violations prompt an ESO to issue a ticket. At the most general level, we can compare violations of monetary and non-monetary standards under the ESA. As Figure 1 illustrates, ESOs are more likely to issue tickets for monetary violations of ES, compared to non-monetary violations. Whereas between 2013/14 to 2015/16 almost a quarter of monetary violations received tickets, during the same period consistently less than $5 \%$ of non-monetary violations were ticketed.

\section{FIGURE 1 HERE}

To better understand how tickets are used in ES enforcement, it is useful to consider ticketing practices in relation to specific ES violations. Figure 2, which presents data pooled across fiscal years 2012/13 to 2015/16, depicts the use of tickets for the following ES monetary violations: overtime pay, minimum wage, public holiday pay, vacation pay, and unpaid wages (the latter violation is not mandated for inspections but is nevertheless assessed occasionally). It also depicts the use of tickets for the following non-monetary ES violations: record keeping, wage statements, poster/postering, and excess daily or weekly hours of work.

In terms of absolute numbers, tickets are most commonly issued for overtime pay violations (306 tickets), public holiday pay violations (454 tickets), and record keeping violations (125 tickets) (Figure 2). Among monetary ES violations, tickets are most prevalent when there are violations of minimum wages (31\% of detected violations). Tickets for violations of overtime pay are the second most prevalent (27\% of detected violations). Finally, ESOs ticket detected unpaid 
wage violations $21 \%$ of the time, and detected holiday pay violations $17 \%$ of the time, both less often than might be expected. ${ }^{5}$

\section{FIGURE 2 HERE}

Overall, ESOs are less likely to ticket non-monetary violations of all sorts than monetary violations. Among non-monetary violations, tickets for record keeping are most common; still, only $6 \%$ of record keeping violations are ticketed. While it is readily understandable why monetary violations are more frequently ticketed than non-monetary violations, the reasons for differences in ticketing between the various non-monetary violations are less obvious.

We can also consider how ticketing practices are influenced by multiple employment standards violations and by the amount of the entitlement associated with violating a monetary ES. On average, workplace inspections with a higher number of violations are more likely to receive a ticket. In inspections where tickets are issued, the average number of monetary violations detected is twice as large as the average number of monetary violations detected in inspections where no ticket is issued. Additonally, as Table 3 shows, inspections that detect both monetary and non-monetary violations are more likely to be ticketed (32\%) than those where only monetary violations are detected $(22 \%)$ or those where only non-monetary violations are detected $(7 \%)$. While it is not surprising that tickets are issued less frequently where only non-monetary violations are detected, we did not expect that multiple monetary violations would be less likely to result in a ticket than a combination of monetary and non-monetary violations. One possible explanation is that inspectors perceive that the combination of poor record keeping and monetary violations creates a high risk of future violations that a ticket might deter.

Not suprisingly, workplace inspections that detected the need for greater restitution for employees, in terms of the dollar amount of unpaid entitlements, are also more likely to result in a ticket. In workplace inspections where a ticket is issued, the median entitlement amount is $\$ 1,576$; in contrast, in workplace inspections where a ticket is not issued this amount was only \$591. Such findings suggest that, consistent with deterrence theory, the greater the number and size of confirmed monetary violations, the higher the likelihood of receiving a ticket.

\section{TABLE 3 HERE}




\section{E. The use of tickets and employer's industry and size}

In general, there appears to be little relationship between an ESO's decision to issue a ticket and either the industry or company size of the workplace concerned (Table 3). An exception is the accommodation and food services industry, where employers are seemingly ticketed more frequently than in the other listed industries. A strategic enforcement approach (Weil, 2008) suggests that greater use of deterrence measures is required in industries that have a higher incidence of violations; the finding may thereby indicate that this approach is having some influence on ticketing practices in Ontario. However, the fact that small employers are more frequent ES violators (Vosko, Noack and Tucker, 2016: 111) but are not more frequently ticketed suggests that the strategic enforcement model is making only limited inroads.

\section{F. The use of tickets and inspection characteristics}

We have indicated that inspections can be divided conceptually into three main types: expanded investigations, targeted or blitz inspections and regular inspections. Here we consider the use of tickets in each of these types of inspection. Table 3 shows that almost $25 \%$ of expanded investigations resulted in a ticket compared to $17 \%$ for targeted inspections and $18 \%$ for regular inspections. One reason for this discrepancy may be that expanded inspections find monetary violations more frequently than other types of inspections and thus arguably represent a critical tool for bridging the reactive and proactive elements of the province's ES enforcement regime (Vosko, Noack and Tucker, 2016: 7, 107).

Tickets are also more common when an ESO has to make multiple visits during the inspection. Only $7 \%$ of inspections where no field visit or only one field visit occurred prompted a ticket. In comparison, half of the inspections where five or more field visits occurred prompted a ticket. Without more information about the reasons why some inspections require multiple field visits, explanations for the increased likelihood of a ticket being issued are necessarily speculative, but to the extent that more field visits are required because non-cooperation or poor record-keeping make it more difficult for ESOs to perform their work, ESOs may view such visits as reasons to signal their displeasure by issuing a ticket.

When we examine the incidence of ticketing with respect to audits, described earlier, not surprisingly we find that tickets are issued more frequently for employers who are required to conduct a self audit (27\%) or who undergo a full audit (25\%) than for employers who are subject 
to a test audit (11\%). This is because self audits are only ordered when test audits find contraventions and full audits are only required when the employer does not complete the test audit (AMES S. 4.7.5). The use of self-audits and full-audits are likely to indicate that an employer has more extensive ES violations, which may also explain why they are more likely to result in tickets.

\section{G. The use of tickets in re-inspections}

A key question centres on whether or not tickets are more commonly issued in instances of repeat violations on a re-inspection. Both strategic enforcement and responsive regulation approaches emphasize the escalation of deterrence measures for repeat violators. The AMES (S. 4.3, 4.4) states that re-inspections should take place either as part of the Ministry's program to monitor levels of compliance or as part of the ESO's performance plan, which establishes a set number of reinspections in a fiscal year. In the latter context, ESOs exercise discretion in selecting employers for re-inspection, but are advised to strongly consider employers to whom the officer previously issued an order to pay wages or fees in the course of a previous inspection or, if the officer found more than one monetary contravention, whether or not any enforcement action was taken. Reinspections should occur at least six months, but no later than twelve months, after the conclusion of the initial inspection. Employers are warned in advance that they will be re-inspected and, indeed, the AMES (S. 4.4) directs ESOs to advise all employers that they may be subject to a reinspection. Although AMES provides advice about the scope of the re-inspection (normally focusing on the standards found previously to have been violated), nothing is said about the appropriate enforcement action if a repeat violation is detected.

The AMES (S. 4.4) also states that, to ensure continuing compliance with the ESA, $10 \%$ of employers are to be re-inspected per fiscal year, although the evidence from Figure 3 indicates that the MOL does not give high priority to re-inspections; the vast majority of employers (93\%) were inspected only once from 2012/13 to 2015/16. ${ }^{6}$ Among those employers inspected only once, $66 \%$ were found to have committed at least one ticketable violation, and ESOs issued tickets in $18 \%$ of those inspections. In comparision, among employers inspected more than once, ESOs detected ticketable violations $83 \%$ of the time on first inspection, and a ticket was issued in $27 \%$ of those inspections. This result is consistent with the AMES recommendation that ESOs should select firms for re-inspection that were previously issued an order to pay or that had more than one monetary violation, regardless of whether previous enforcement action was taken. The fact that an 
ESO detected a monetary violation or issued a ticket on the first inspection increases the likelihood of that employer being selected for a re-inspection. Employers who were inspected more than once also tended to have higher employee entitlements on their first inspection compared to employers who were only inspected once.

\section{FIGURE 3 HERE}

The next question is whether ESOs issue tickets more frequently when they detect ticketable violations on a re-inspection. Figure 3 shows us that while $41 \%$ of all re-inspected employers had a ticketable violation on subsequent inspection, only $28 \%$ of such offenders were issued a ticket. However, in Figure 3 the focus is on all inspections which does not differentiate between employers who only had ticketable violations on their first inspection and those who did not. We turn, therefore, to Figure 4, which presents only those 477 re-inspected employers who had a ticketable violation on their first inspection.

\section{FIGURE 4 HERE}

Among the $27 \%$ of employers who were issued a ticket on their first inspection, $33 \%$ were found to have re-offended on the re-inspection, but only $19 \%$ of these employers were issued tickets. On the other hand, among the $73 \%$ of employers who had a ticketable violation but were not issued a ticket, $42 \%$ had violations on their re-inspection and of these $31 \%$ were issued tickets. These results suggest that receiving a ticket on a first inspection is indeed associated with less likelihood of employers having a ticketable violation on a re-inspection. This finding is consistent with the view that tickets have a specific deterrent effect and reduces the likelihood of a subsequent violation. However, it is also peculiar that ESOs are less likely to issue a ticket to a re-offending employer who did not learn from their first ticket than they are to issue a ticket to a re-offending employer who was not ticketed in the first instance since all enforcement theories indicate that employers who re-offend after receiving a ticket should face escalating penalties, whereas clearly they do not. However, employers who enjoyed the benefit of ESO discretion and were not ticketed on their initial inspection - despite the presence of a ticketable violation - were treated more harshly when they were found to have re-offended on re-inspection, a finding consistent with the recommendations of the various enforcement theories discussed. 


\section{H. Predicting when tickets are issued}

To further reveal how different criteria are related to the issuance of tickets in workplace inspections, a logistic regression model is used to examine whether or not an inspection where a ticketable violation is detected and recorded is likely to yield a ticket based on the following criteria: company size, industry, type of inspection, entitlement amount, number of field visits, type of audit completed, and fiscal year (see Table 4). The merit of applying this type of model is that it determines the independent effect of each of these characteristics and their relation to whether or not a ticket is issued. The results generally mirror the results from the bivariate analysis presented earlier. As observed previously, company size does not have a substantial effect. Companies that are associated with public or private service industries are slightly less likely to be ticketed compared to companies in the accommodation and food services industry. However, complementing the descriptive findings above, a model of this sort underscores the importance of inspection characteristics (i.e., inspection type, number of field visits etc.) in predicting when tickets will be issued. As total entitlement amounts increase, there is also an incremential increase in the likelihood of being issued a ticket. However, there is little difference between inspections with entitlement amounts of less than $\$ 300$ and inspections where only non-monetary violations are assessed. Compared to regular inspections, tickets are more likely to be issued in expanded investigations. Similarly, the odds of being issued a ticket increase for each additional field visit by an ESO. For example, the odds of being issued a ticket when five or more field visits take place

during an inspection are over nine times higher than when one or fewer field visits take place. Inspections where the employer completed a self-audit or the ESO completed a full audit are also more likely to yield a ticket compared to inspections where the ESO only conducts a test audit.

\section{TABLE 4 HERE}

\section{Discussion}

Theoretical perspectives on the use of deterrence measures provide context for understanding these empirical results. First, these findings demonstrate that tickets are used far more frequently in workplace inspections than they are in the investigation of individual complaints; they thus provide a more nuanced picture of the use of deterrence measures in Ontario than was possible in our 
previous study of deterrence writ large. That said, the prevalence of tickets, at least when measured against detected and recorded ticketable violations, is low - fewer than one in ten. As a result, most employers can expect that, even if they are inspected and a violation is detected, the most likely consequence is that they will be required to correct the violation, either by paying what they owe in the case of monetary violations or by complying in the future with record keeping and other similar obligations. From a deterrence perspective, the prevalence of ticketing on inspections is still exceedingly low.

Our results also reveal some more specific patterns in the use of tickets. Detected monetary violations are more likely to be ticketed than non-monetary violations and, among monetary violations, overtime pay, minimum wage, and public holiday pay violations are most likely to result in tickets. Employers with multiple violations, particularly if there are both monetary and non-monetary violations, are more likely to be ticketed than employers with a single detected violation and, where there is a monetary violation, the likelihood of being ticketed increases with the amount owed. All of these findings are consistent with the deterrence theory perspective that the greater the number and seriousness of violations, the harsher treatment they should receive.

However, there is a serious question as to whether ticketing, no matter its frequency, achieves a deterrent effect. To our knowledge, there has been no previous research into the deterrent effect of tickets in the literature on ES; however, the issue has received more attention in the context of occupational health and safety regulation. In a study of workplace health and safety (WHS) enforcement in Australia, Bluff and Johnstone (2003) discussed issues arising out of the use of 'infringement notices' (equivalent to tickets). They found that such notices may be appropriately used to deal with minor offences particularly if unwitting. But they raised a concern that notices might turn offences into 'purchasable commodities' that have little deterrent effect (Bluff and Johnstone, 2003: 341-42).

In principle, whether or not notices or tickets have a deterrent effect is an empirical question, but one on which there has been limited research. Gunningham et al. (1998: 338-339) interviewed Australian policy-makers, inspectors, industry partners, and recipients of infringement notices, and found that most respondents believed that despite a short-term positive effect on compliance, that improvements were more likely to be sustained if resources were provided for continuing enforcement. Subsequent research on WHS enforcement has tended to confirm that inspections with penalties have strong specific deterrent effects, but limited general deterrent effects. For 
example, Gray and Scholz (1993) found while brief inspections without penalties had no injuryreducing effects, those that included even small penalties significantly reduced injuries and lost work days. A recent systematic review of the WHS enforcement literature by Tompa et al. (2016) found strong evidence that inspections involving penalties are effective and moderate-to-limited evidence that those finding wrongdoing but absent penalties are ineffective. The authors concluded that this finding 'reinforces the importance of regulators being out in the field identifying and citing/penalizing non-compliance' (Tompa et al., 2016: 929). More recently, Hardy and Howe (2017) found in the context of ES enforcement in Australia that targeted enforcement campaigns have a modest general deterrence ripple effect and that the size of the penalty is less important.

Our study provides some evidence on the specific deterrent effects of inspections and ticketing in Ontario ES enforcement. Figure 3 shows that of the 573 employers inspected more than once, $477(83 \%)$ had ticketable violations on their first inspection, but only $41 \%$ of these employers had ticketable offences on their second. This decrease in the prevalence of ticketable violations on reinspection suggests that inspections reduce the likelihood that an employer will re-offend in the six to twelve-month period following the inspection, but it does not tell us about the relative deterrent effect of inspections with and without penalties. Figure 4 enables us to analyse these effects by differentiating between employers who were ticketed on the first inspection and those who were not. Among those employers who had ticketable violations but were not ticketed on their first inspection, $42 \%$ were found to have re-offended on re-inspection. By contrast, among employers who were ticketed on their first violation, only $33 \%$ were found to have re-offended on a re-inspection. These data suggest that inspections with tickets have a marginally greater deterrent effect than inspections without tickets. However, they also provide evidence that inspections without tickets, coupled with a warning that the employer may be re-inspected, also have a specific deterrent effect, supporting the view that proactive inspections of all kinds should be a prominent part of any enforcement strategy.

When viewed from the perspective of responsive regulation and the enforcement pyramid, a relatively low rate of ticketing on first inspections is justified on the basis that employers with detected violations should be given the benefit of the doubt that their violations were inadvertent. However, that presumption should give way in the face of evidence to the contrary, such as the presence of multiple violations, particularly those involving large sums of money owing to employees. Our findings suggest that ESOs have incorporated that perspective in regard to 
ticketing on first inspections. However, as this study and OHS studies demonstrate, such an approach comes at the cost of foregoing the greater specific deterrent effects that inspections with tickets produce.

The pattern of ticketing on re-inspections is more problematic from the pyramid perspective. Employers with a ticketable violation on a re-inspection are not more likely to be ticketed than those who had a ticketable violation on their first inspection. However, when we narrowed the analysis to employers who had a ticketable violation on the first inspection and who re-offended on the second, we found that the enforcement pyramid seemed to apply in regard to employers who were not ticketed in the first instance, but that those employers who were ticketed on the first inspection faced a reduced likelihood of being ticketed for a repeat violation.

Perhaps in an attempt to better address the problem of lax treatment of re-offending employers, Ontario conducted an enforcement blitz in 2016, targeting employers with prior ES violations. In announcing the blitz, the government declared that it was adopting a zero-tolerance policy, which presumably indicated that repeat violators would face a penalty. In practice, however, nothing of this sort happened. Of the 104 employers who were re-inspected in the context of the blitz, 77 were found to be in violation again. Yet only 15 NOCs and 27 tickets were issued (Ontario MOL, 2017; Mojtehedzadeh, 2017). Even assuming that no employer received multiple tickets or NOCs, the result is that only $55 \%$ of repeat offenders were subject to low-level deterrence measures. Thus, despite the promise of adherence to a strict enforcement pyramid in this blitz, it did not materialise. Finally, from the perspective of strategic enforcement, it is arguable that, as a general matter, the deterrence leg of the strategy is under-used. More specifically, although there is some evidence that at least one industry, accommodation and food services (likely to be a site of high levels of violations) is ticketed somewhat more frequently than other industries, the difference is small. As well, small employers, also known as a location of more frequent ES violations, are not more likely to receive tickets. While this practice might be justified in strategic enforcement if there was a targeted effort to engage entities at the top of the supply chain to secure compliance at the bottom, no initiatives of this sort are yet underway in Ontario.

\section{Conclusion}

In recent years, the Ontario government has modestly shifted its approach to ES enforcement toward greater use of proactive inspections with tickets when violations are detected. This shift is 
likely to continue. In 2017 special advisors appointed to conduct the Changing Workplaces Review (2017) recommended allocating more resources to proactive enforcement, increasing the use of targeted inspections and expanded investigations and increasing penalties for tickets and NOCs.

The government embraced the idea of strengthening enforcement and committed to hiring as many as 175 new ESOs by 2021, inspecting 1 in 10 Ontario workplaces annually, and better targeting enforcement resources on employers who violate the ESA (Government of Ontario, 2017). However, while it enacted legislation that would permit a flexible schedule of penalties for NOCs, the government did not increase the set fines for tickets (Fair Workplaces, Better Jobs Act, 2017).

Our research broadly supports increased use of proactive inspections with low-level penalties. Of course, we recognise that proactive inspections and deterrence are only one leg of an effective enforcement strategy, but given the long history of compliance-based approaches that minimise the role of proactive enforcement and penalties, often in response to active resistance, our research provides empirical support for maintaining a healthy role for deterrence in the enforcement mix.

\section{Funding}

The research for this article was funded by a Partnership Grant, titled 'Closing the Employment Standards Enforcement Gap: Improving Protections for People in Precarious Jobs', funded by the Social Sciences and Humanities Research Council of Canada (SSHRC).

\section{Acknowledgements}

This article is the product of equal authorship. The authors would like to thank Alan Hall for his helpful comments on an earlier version of this text and Heather Steel for her administrative assistance on various fronts. We are also grateful to SSHRC for its support and to members of the larger research team for their contributions to this larger endeavour.

\section{References}

Administrative Manual for Employment Standards (AMES) (2017) Ontario Ministry of Labour. Ayres I and Braithwaite J (1992) Responsive Regulation: Transcending the Deregulation Debate. Oxford, UK: Oxford University Press.

BC [British Columbia] Employment Standards Coalition (2017) Workers' stories of exploitation and abuse: why BC employment standards need to change. Burnaby, BC, May. 
Bluff L and Johnstone R (2003) Infringement notices: stimulus for prevention or trivialising offences? Journal of Occupational Health and Safety - Australia and New Zealand 19(4): 337-45.

Burns EM (1926) Wages and the State. London, UK: PS King and Son.

Changing Workplaces Review (2017) Final Report. May. (C. Michael Mitchell and John C. Murray, Special Advisors). Available at: https://files.ontario.ca/books/mol_changing_workplace_report_eng_2_0.pdf (accessed 28 October 2017).

Dickens L (2012) Fairer workplaces: making employment rights effective. In: Dickens L (ed.) Making Employment Rights Effective. Oxford, UK: Hart Publishing, pp. 205-28.

Fair Workplaces, Better Jobs Act (2017) Statute of Ontario, 2017, c. 22.

Gesualdi-Fecteau D and Vallée G (2016) Labor inspection and labor standards enforcement in Quebec: contingencies and intervention strategies. Comparative Labor Law \& Policy Journal 37(2): 339-75.

Government of Ontario (2017) Backgrounder: proposed changes to Ontario's employment and labour laws. May 30. Available at: https://news.ontario.ca/mol/en/2017/05/proposedchanges-to-ontarios-employment-and-labour-laws.html (accessed 29 October 2017).

Gray W and Scholz J (1993) Does regulatory enforcement work? A panel analysis of OSHA enforcement. Law and Society Review 27(1): 177-213.

Gunningham N, Sinclair D and Burritt P (1998) On-the-spot fines and the prevention of injury and disease - the experience of Australian workplaces. Sydney: National Occupational Health and Safety Commission, May.

Hardy T (2016) Who should be held liable for workplace contraventions and on what basis? Australian Journal of Labour Law 29(10): 78-109.

Hardy $\mathrm{T}$ and Howe $\mathrm{J}$ (2017) Creating ripples, making waves? assessing the general deterrence effects of enforcement activities of the fair work ombudsman. Sydney Law Review 39(4): 471-500.

Hawkins K (1984) Environment and Enforcement. Oxford, UK: Clarendon Press.

Kagan RA (1984) On regulatory inspectorates and police. In: Hawkins K and Thomas JM (eds) Enforcing Regulation. Boston, MA: Kluwer, pp. 37-64.

Levine M (2018) Behind the minimum wage fight, a sweeping failure to enforce the law. Politico, 18 February. Available at: https://www.politico.com/story/2018/02/18/minimum-wage-not-enforced-investigation409644 (accessed 2 March 2018).

Mojtehedzadeh S (2017) Bosses who broke law haven't learned their lesson, labour ministry blitz finds. Toronto Star, 15 March. Available at: https://www.thestar.com/news/gta/2017/03/15/bosses-who-broke-law-havent-learnedtheir-lesson-labour-ministry-blitz-finds.html (accessed 14 March 2018).

Ontario MOL [Ministry of Labour] (2004) McGuinty government steps up employment standards enforcement. Ministry of Labour, 14 July. Available at: https://news.ontario.ca/archive/en/2004/07/14/McGuinty-government-steps-upemployment-standards-enforcement.html

Ontario [MOL] Ministry of Labour (2017) Blitz results: repeat violators/zero tolerance 2016, January. Available at: https://www.labour.gov.on.ca/english/es/inspections/blitzresults_rvzt2016.php (accessed 28 October 2017). 
Ontario [MOL] Ministry of Labour (2017) Backgrounder: Proposed Changes to Ontario's Employment and Labour Laws, 30 May. Available at: https://news.ontario.ca/mol/en/2017/05/proposed-changes-to-ontarios-employment-andlabour-laws.html (accessed 17 March 2018).

Tompa E, Kalcevich C, Foley M et al. (2016) A systematic literature review of the effectiveness of occupational health and safety regulatory enforcement. American Journal of Industrial Medicine 59(11): 919-933.

Tucker E (2017) When wage theft was a crime in Canada. Osgoode Hall Law Journal 54(3): 933-58.

Vosko L, Noack A and Tucker E (2016) Employment standards enforcement: a scan of employment standards complaints and workplace inspections and their resolution under the Employment Standards Act, 2000. Research Report for the Ontario Ministry of Labour to support the Changing Workplaces Review, March.. Available at: https://cirhr.library.utoronto.ca/sites/cirhr.library.utoronto.ca/files/researchprojects/Vosko\%20Noack\%20Tucker-\%206A\%20-ESA\%20Enforcement.pdf (accessed 27 October 2017).

Weil D (2008) A strategic approach to labour inspection. International Labour Review 147(4): $349-375$.

Weil D (2010) Improving Workplace Conditions Through Strategic Enforcement: A Report to the Wage and Hour Division. Boston, Mass.: Boston University.

Weil D (2014) The Fissured Workplace. Cambridge, MA: Harvard University Press.

\section{Author biographies}

Rebecca Casey is a Postdoctoral Fellow, working in the Closing the Employment Standards Enforcement Gap research partnership, at York University, Toronto, Canada.

Eric Tucker is Professor of Law, at Osgoode Hall Law School, York University, Toronto. He has published extensively in the fields of occupational health and safety regulation and labour law. He has been involved in law reform initiatives through his participation on the board of Injured Workers' Consultants, a community legal clinic, and co-authored a study of the legal definition of employment for the Law Commission of Canada.

Leah F. Vosko is Professor of Political Science and Canada Research Chair in the Political Economy of Gender \&Work, at York University, Toronto. She is known for her work in political economy and her writing on such topics as work, gender, citizenship, migration and labour markets, and has published extensively on the reworking of the standard employment relationship, labour standards and the growth of precarious employment.

Andrea M. Noack is Associate Professor of Sociology at Ryerson University, Canada, where she investigates the history and politics of knowledge production in Canada, including how practices of survey design contribute to regulation. Her participation in community-engaged research includes investigating working conditions in Canada's public sector, precarious work in Ontario, and the enforcement of employment standards. 
Table 1: Comparing the use of tickets and Notices of Contravention in workplace inspections and individual complaints

\begin{tabular}{|c|c|c|c|c|}
\hline & 2012/13 & 2013/14 & 2014/15 & 2015/16 \\
\hline \multicolumn{5}{|l|}{ PART I TICKETS } \\
\hline \multicolumn{5}{|l|}{ Complaints } \\
\hline Ticketable Violations & -- & 11,751 & 10,196 & -- \\
\hline Part I Tickets & -- & 121 & 186 & -- \\
\hline$\%$ of Ticketable Violations with Tickets & -- & $1.0 \%$ & $1.8 \%$ & -- \\
\hline \multicolumn{5}{|l|}{ Inspections } \\
\hline Ticketable Violations & 4,870 & 3,723 & 2,781 & 4,907 \\
\hline Part I Tickets & 298 & 348 & 259 & 450 \\
\hline$\%$ of Ticketable Violations with Tickets & $6.1 \%$ & $9.3 \%$ & $9.3 \%$ & $9.2 \%$ \\
\hline \multicolumn{5}{|l|}{ NOTICES OF CONTRAVENTION } \\
\hline \multicolumn{5}{|l|}{ Complaints } \\
\hline Total Number of Violations & 12,079 & 12,071 & 10,476 & -- \\
\hline Notices of Contravention & 60 & 79 & 68 & -- \\
\hline$\%$ of Complaints with Notices of Contravention & $0.5 \%$ & $0.7 \%$ & $0.6 \%$ & -- \\
\hline \multicolumn{5}{|l|}{ Inspections } \\
\hline Total Number of Violations & 4,958 & 3,786 & 2,849 & 4,676 \\
\hline Notices of Contravention & 42 & 20 & 34 & 35 \\
\hline$\%$ of Inspections with Notices of Contravention & $0.8 \%$ & $0.5 \%$ & $1.2 \%$ & $0.7 \%$ \\
\hline
\end{tabular}

Source: ESIS data 2012/13 to 2015/16

Note: Data for complaints are not available for 2015/16 as complaints take longer to process than inspections. Data on tickets in complaints for 2012/13 are suppressed due to small counts. 
Table 2: Prevalence of ticketable violations and the use of tickets in workplace inspections, by fiscal year

\begin{tabular}{|c|c|c|c|c|c|}
\hline & $2012 / 13$ & 2013/14 & $2014 / 15$ & $2015 / 16$ & Total \\
\hline Total Number of Inspections & 2,349 & 1,902 & 1,747 & 2,548 & 8,546 \\
\hline Number of Inspections with Ticketable Violations & 1,674 & 1,297 & 989 & 1,621 & 5,581 \\
\hline$\%$ of Inspections with Ticketable Violations & $71.3 \%$ & $68.2 \%$ & $56.6 \%$ & $63.6 \%$ & $65.3 \%$ \\
\hline Number of Inspections with One or More Tickets Issued & 259 & 280 & 207 & 330 & 1,076 \\
\hline$\%$ of Inspections with Ticketable Violations with One or More Tickets Issued & $15.5 \%$ & $21.6 \%$ & $20.9 \%$ & $20.4 \%$ & $19.3 \%$ \\
\hline
\end{tabular}

Source: ESIS data 2012/13 to 2015/16 
Table 3: Characteristics of workplace inspections with ticketable violations where tickets are issued, 2012/13 to 2015/16 (pooled)

\begin{tabular}{|c|c|c|}
\hline & $\begin{array}{l}\text { Ticket Not } \\
\text { Issued }\end{array}$ & $\begin{array}{l}\text { Ticket } \\
\text { Issued }\end{array}$ \\
\hline \multicolumn{3}{|l|}{$\begin{array}{l}\text { ES VIOLATION CHARACTERISTICS } \\
\text { Type of Violations (Inspections with Multiple } \\
\text { Violations) }\end{array}$} \\
\hline Two or More Non-Monetary Violations & $93.3 \%$ & $6.7 \%$ \\
\hline Two or More Monetary Violations & $77.7 \%$ & $22.3 \%$ \\
\hline $\begin{array}{l}\text { Both Monetary and Non-Monetary Violations } \\
\text { Total Entitlement Amount }\end{array}$ & $68.2 \%$ & $31.8 \%$ \\
\hline Median & $\$ 591$ & $\$ 1,576$ \\
\hline \multicolumn{3}{|l|}{$\begin{array}{l}\text { EMPLOYER CHARACTERISTICS } \\
\text { Industry }\end{array}$} \\
\hline Accommodation and Food Services & $77.7 \%$ & $22.3 \%$ \\
\hline Manufacturing and Primary Industries ${ }^{a}$ & $80.5 \%$ & $19.5 \%$ \\
\hline Retail Trade & $81.9 \%$ & $18.1 \%$ \\
\hline Service Industries - primarily private-sector ${ }^{b}$ & $83.3 \%$ & $16.7 \%$ \\
\hline Service Industries - primarily public-sector ${ }^{c}$ & $84.4 \%$ & $15.6 \%$ \\
\hline \multicolumn{3}{|l|}{ Company Size } \\
\hline 1 to 5 employees & $81.7 \%$ & $18.3 \%$ \\
\hline 6 to 10 employees & $82.0 \%$ & $18.0 \%$ \\
\hline 11 to 19 employees & $79.9 \%$ & $20.1 \%$ \\
\hline 20 to 49 employees & $79.3 \%$ & $20.7 \%$ \\
\hline 50 or more employees & $81.5 \%$ & 18.5 \\
\hline
\end{tabular}

\section{INSPECTION CHARACTERISTICS}

\section{Type of Inspection}

Expanded

$75.1 \%$

$24.9 \%$

Targeted and THA Blitz

$82.9 \%$

$17.1 \%$

Regular

$81.7 \%$

$18.3 \%$

Others

$83.3 \%$

$16.7 \%$

Number of Field Visits

0 or 1 Visit

$93.0 \%$

$7.0 \%$

2 Visits

$81.8 \%$

$18.2 \%$

3 Visits

$75.3 \%$ 
4 Visits

$5+$ Visits

Type of Audit Completed

Test Audit

Self Audit

Full Audit

No Audit
$62.7 \%$

$50.0 \%$

$89.1 \%$

$73.4 \%$

$75.0 \%$

$79.6 \%$
$37.3 \%$

$50.0 \%$

$10.9 \%$

$26.6 \%$

$25.0 \%$

$20.4 \%$

Source: ESIS data 2012/13 to $2015 / 16$

Note:

${ }^{a}$ Industries include: agriculture, forestry, fishing, mining, oil, gas, utilities, construction, manufacturing, wholesale trade, transportation, and warehousing

${ }^{\mathrm{b}}$ Industries include: finance, insurance, real estate, leasing, professional, scientific and technical services, management, and administrative and other support services

${ }^{\mathrm{c}}$ Industries include: include: educational services, health care and social assistance, public administration, information, culture, and recreation 
Table 4: Logistic regression modelling the probability of a workplace inspection yielding a ticket, 2012/13 to 2015/16 (pooled)

\begin{tabular}{|c|c|c|}
\hline & B & $\begin{array}{l}\text { Odds } \\
\text { Ratio }\end{array}$ \\
\hline \multicolumn{3}{|l|}{ Company Size } \\
\hline 1 to 5 employees (reference) & 0.00 & 1.00 \\
\hline 6 to 10 employees & -0.27 & 0.76 \\
\hline 11 to 19 employees & -0.13 & 0.88 \\
\hline 20 to 49 employees & -0.20 & 0.82 \\
\hline 50 or more employees & -0.30 & 0.74 \\
\hline Missing company size information & -0.37 & 0.69 \\
\hline \multicolumn{3}{|l|}{ Industry (based on the NAICS) } \\
\hline Accommodation and Food Services (reference) & 0.00 & 1.00 \\
\hline Manufacturing and Primary Industries ${ }^{a}$ & -0.10 & 0.91 \\
\hline Retail Trade & -0.16 & 0.85 \\
\hline Service Industries - primarily private-sector ${ }^{\mathrm{b}}$ & -0.30 & 0.74 \\
\hline Service Industries - primarily public-sector ${ }^{c}$ & -0.39 & 0.68 \\
\hline \multicolumn{3}{|l|}{ Type of Inspection } \\
\hline Regular (reference) & 0.00 & 1.00 \\
\hline Expanded Investigation & 0.36 & 1.43 \\
\hline Targeted and THA Blitz & 0.14 & 1.15 \\
\hline Other & 0.03 & 1.03 \\
\hline \multicolumn{3}{|l|}{ Entitlement Amounts } \\
\hline Less than $\$ 300$ (reference) & 0.00 & 1.00 \\
\hline$\$ 300$ to $\$ 999$ & 0.77 & 2.17 \\
\hline$\$ 1,000$ to $\$ 1,999$ & 1.12 & 3.07 \\
\hline$\$ 2,000$ to $\$ 9,999$ & 1.44 & 4.24 \\
\hline$\$ 10,000$ or more & 1.97 & 7.17 \\
\hline Non-Monetary & -0.07 & 0.93 \\
\hline \multicolumn{3}{|l|}{ Number of Field Visits } \\
\hline 0 or 1 Visit (reference) & 0.00 & 1.00 \\
\hline 2 Visits & 1.00 & 2.71 \\
\hline 3 Visits & 1.22 & 3.37 \\
\hline 4 Visits & 1.83 & 6.24 \\
\hline $5+$ Visits & 2.24 & 9.38 \\
\hline \multicolumn{3}{|l|}{ Type of Audit Completed } \\
\hline Test Audit (reference) & 0.00 & 1.00 \\
\hline
\end{tabular}




\begin{tabular}{lll} 
Self Audit & 0.26 & 1.29 \\
Full Audit & 0.36 & 1.43 \\
No Audit & 0.65 & 1.91 \\
Fiscal Year & & \\
$2012 / 13$ (reference) & 0.00 & 1.00 \\
$2013 / 14$ & 0.42 & 1.53 \\
$2014 / 15$ & 0.44 & 1.55 \\
$2015 / 16$ & 0.35 & 1.42 \\
\hline
\end{tabular}

Source: ESIS data 2012/13 to 2015/16

Note:

${ }^{a}$ Industries include: agriculture, forestry, fishing, mining, oil, gas, utilities, construction, manufacturing, wholesale trade, transportation, and warehousing

${ }^{\mathrm{b}}$ Industries include: finance, insurance, real estate, leasing, professional, scientific and technical services, management, and administrative and other support services

${ }^{\mathrm{c}}$ Industries include: include: educational services, health care and social assistance, public administration, information, culture, and recreation 


\section{Figure 1: Percentage of ticketable violations which result in tickets}

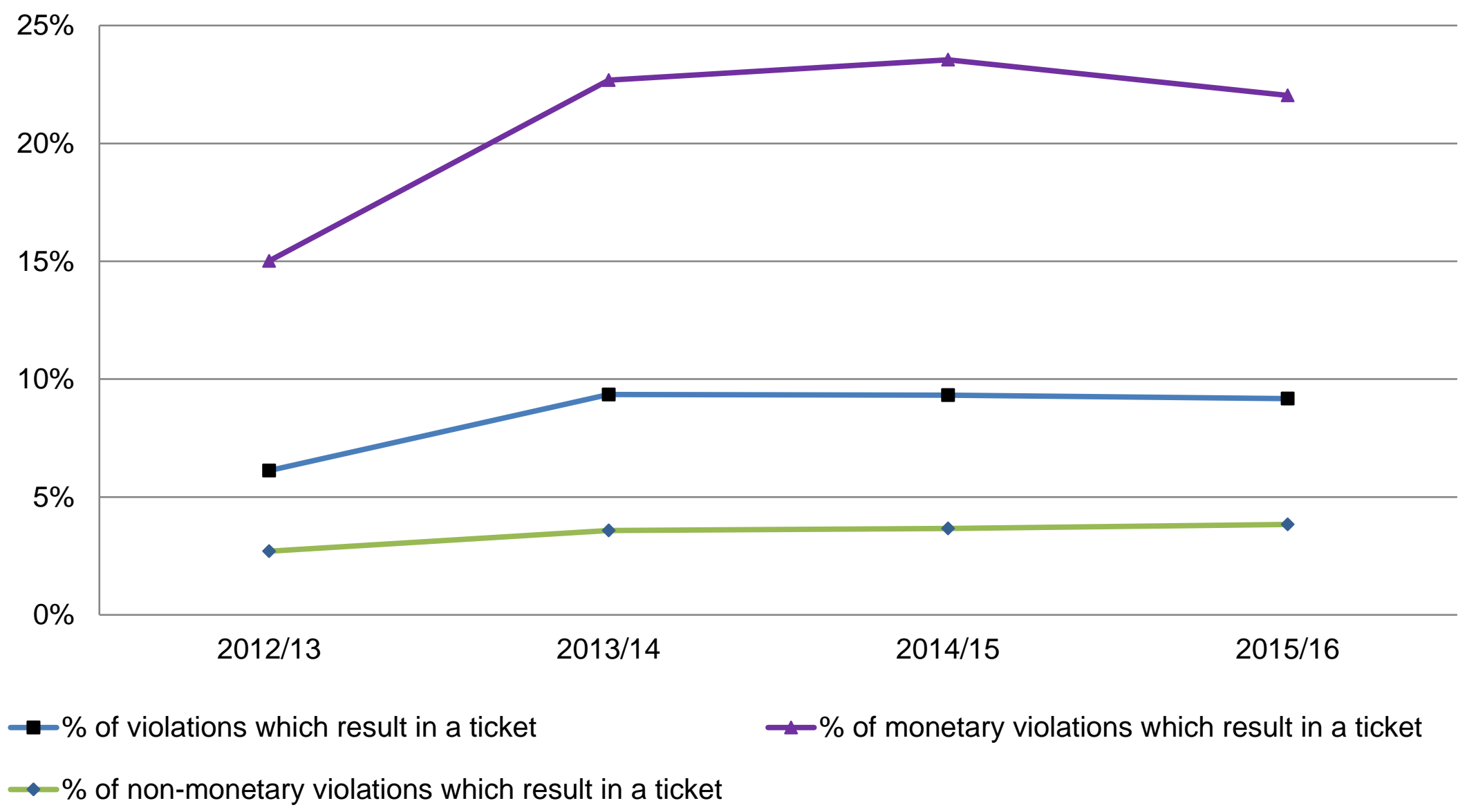

Source: ESIS data 2012/13 to 2015/16 
Figure 2: Percentage and number of tickets issued, by violation (2012/13 to 2015/16, pooled)

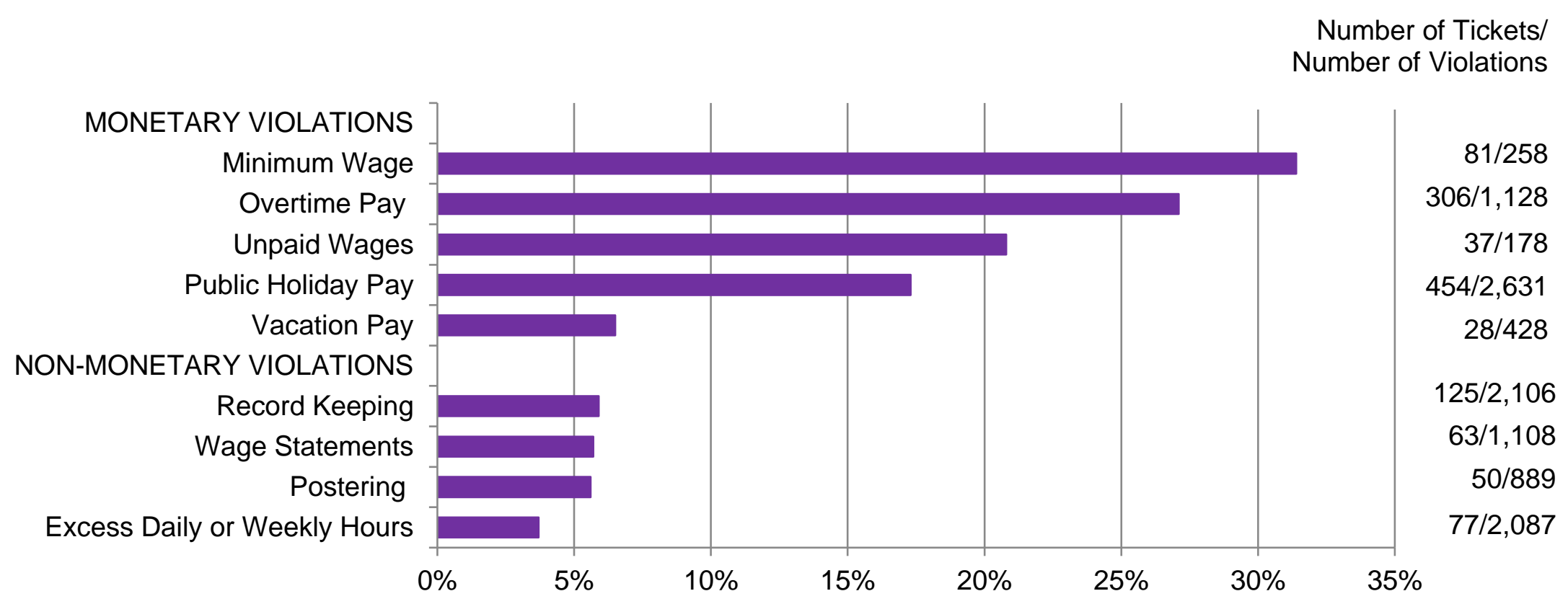

Source: ESIS data 2012/13 to 2015/16

Note:

When violations are detected and recorded in workplace inspections, they typically include multiple ticketable offences. Ticketable offences were categorized into the above monetary and non-monetary violations based on the ESA sections that were specified in the record. 
Figure 3: The use of tickets in first inspections or re-inspections, all inspected employers

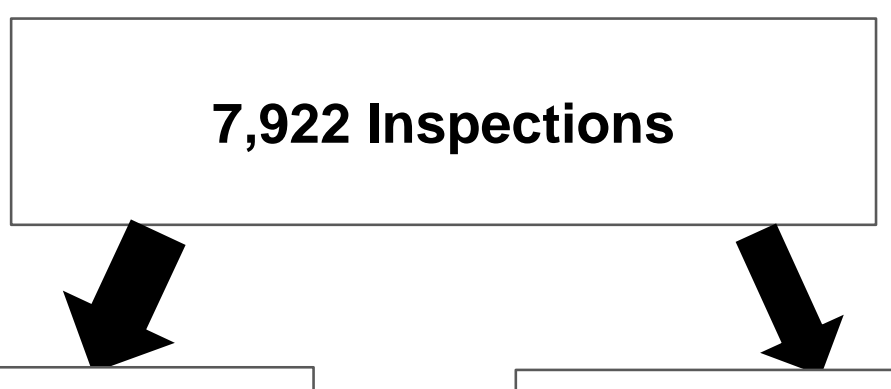

7,349 Employers Inspected only once

573 Employers with More than One Inspection
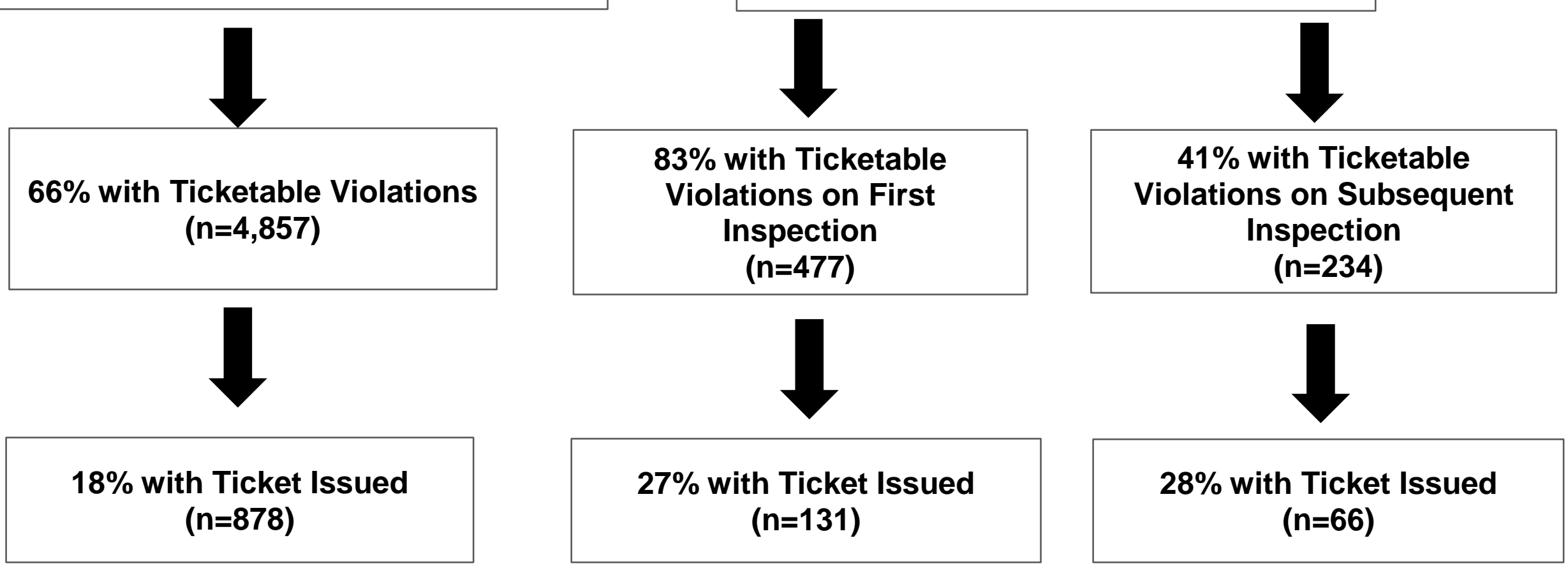
Figure 4: The use of tickets for repeat inspections, employers with ticketable violations in first inspection

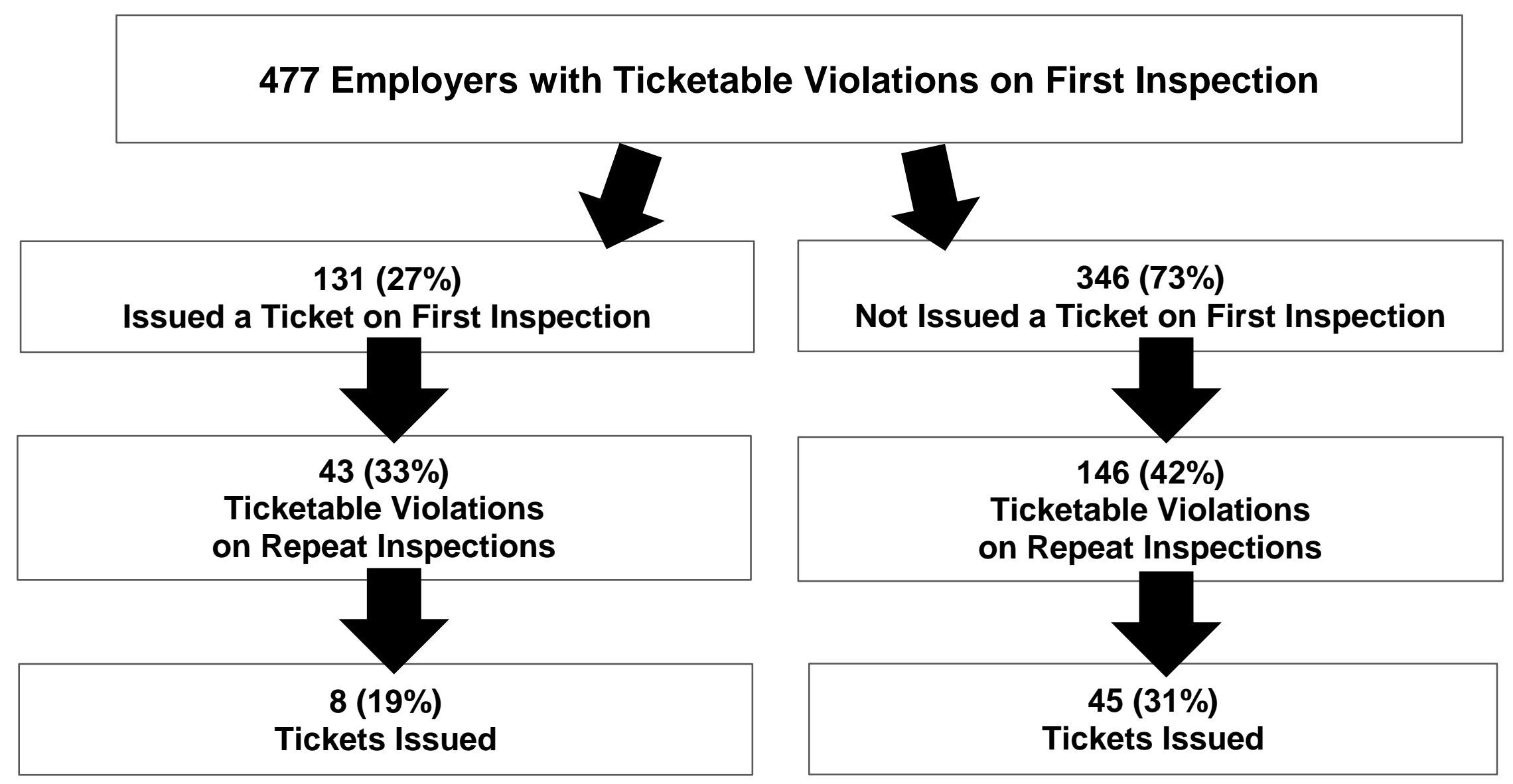


${ }^{1}$ Access to data from ESIS was acquired under a unique data-sharing agreement with the MOL. We are grateful to this Ministry and its staff for engaging in this agreement and for supporting the larger research partnership from which this article emanates.

${ }^{2}$ This analysis uses the government fiscal year, which runs from April $1^{\text {st }}$ to March $31^{\text {st }}$.

${ }^{3}$ A smaller number of inspections are classified as 'other' inspections: these include reinspections or inspections of previous ES violators, inspections that result from an employer completing the MOL's online 'compliance check' (self-audit) tool, or those that are specifically prompted by other ESOs, regional and district managers, or the staff of the EPB.

${ }^{4}$ ESOs conducting inspections may not record every violation they detect. For example, an ESO may inspect a workplace and find that the employer has failed to post a mandatory poster. Rather than record this as a violation, the ESO may simply provide the employer with a poster, which is immediately posted, and continue the inspection. Thus, we stipulate that the violation must be both detected and recorded.

5 The relatively low number of unpaid wage violations and the low use of tickets for these violations may be attributable to the fact that unpaid wages are not one of the 11 designated standards that ESOs are required to review in inspections; this is not the case, however, for vacation pay violations.

${ }^{6}$ This percentage may understate the actual frequency of repeat inspections as it is possible that an insufficient amount of time lapsed for repeat inspections to be undertaken among those employers inspected in 2015/16. 